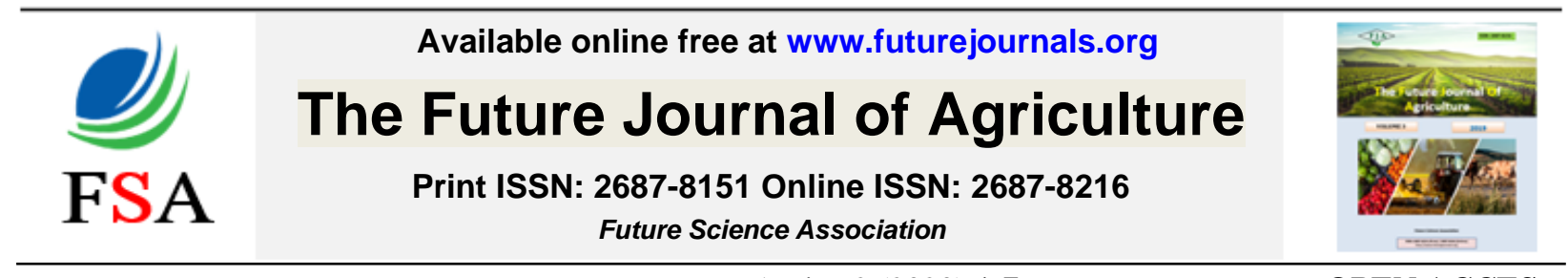

Future J. Agric., 2 (2020) 1-7

OPEN ACCES

DOI: $10.37229 /$ fsa.fja.2020.06.10

\title{
IMPROVING THE VEGETATIVE GROWTH OF FRUIT SEEDLINGS AND THEIR MINERAL ELEMENTS USING LIQUID ORGANIC FERTILIZERS (Review Article)
}

\author{
Ayad H. Alalaf ${ }^{1^{*}}$ and Mohamed M. Ibrahim ${ }^{2}$ \\ ${ }^{1}$ Hort. \& Landscape design Dept., College of Agriculture and Forestry, Mosul Univ., Iraq. \\ ${ }^{2}$ Hort. Dept., Fac. Agric., Zagazig Univ., Egypt.
}

*Corresponding author: ayad_alalaf@uomosul.edu.iq Received: 10 May 2020 ; Accepted: 10 Jun. 2020

\begin{abstract}
Clean agriculture is defined as a method of agricultural production that avoids the use of chemicals, especially fertilizers and pesticides, and on this basis, this agriculture, including organic, has a positive impact because it depends on available natural resources, which in turn reduces environmental pollution resulting from the use of chemical fertilizers and improving the environment And food security, and organic fertilizers of various types are an important and essential source of the elements needed by the larger and smaller plants as well as its very important role in improving the physical, chemical and biological soil properties, and in recent times. The importance of using liquid organic fertilizers has emerged as one of the most important clean alternatives to the nutrients needed for fruit seedlings, because it contains some organic acids such as humic and fulvic acids and amino acids and other substances that are cheap and easy to use and low pollution to the environment and agricultural products and their contribution to improving physical, chemical and biological characteristics soil, which is reflected positively in the growth and production of different plants.
\end{abstract}

Key words: Fruit seedlings, liquid organic, fertilization, vegetative growth, mineral elements.

\section{INTRODUCTION}

A long time ago, it became certain that organic fertilizers of various types constitute an important and essential source for the elements needed by large and small plants, and they are extremely important for fruit orchards. Plants have a great importance in improving the physical, chemical, and biological properties of soil by dismantling heavy soil grains and improving their aerating (Alalaf, 2019) and the organic matter contributes to increasing vital activity within the root-spreading area because it contains some microbes. It is one of the natural enhancements that play an important and effective role in improving the natural properties (AlcaAntara et al., 2016 and Adiaha, 2017), in addition to its important role in increasing the ability of the soil to retain water, especially light-weight lands such as sandy lands, in addition to so when decomposed, it produces many organic acids that reduce the $\mathrm{pH}$ of the soil, increasing the readiness of a number of nutrients in the soil. It also helps to warm the soil, especially in the winter at the root zone, and the organic matter also plays a great importance in creating physical conditions suitable for root growth and penetration and obtaining a good balance between soil water and air by linking the soil minutes in fixed groups divided for disintegration and demolition, which gives the final image to build the soil, the use of organic fertilizers has increased in recent times to reduce environmental and food pollution resulting from overuse of mineral fertilizers (Mansour and Shaaban, 2007; Alwan and Al-Hamdani, 2012 and Barakat et al., 2012). The sources of the organic matter are varied from plants derived from the roots of plants and 
leaves falling on the surface of the soil, which go through phases of biological decomposition due to microorganisms, to plants grown to fluctuate in the soil, such as green manure plants and plant waste that are added to the soil to increase their productivity and improve their characteristics and animal sources that come as a result of revitalization activities. Soil, its cells and its tissues after its death, as well as human and animal waste added to the soil (AlMawsali, 2019).

Components of organic materials: It was found that the organic matter has two main components according to what Schnitzer (1991) mentioned, namely:

1. Non-humid substances that constitute (20$30 \%$ ) of the total organic matter, which are decomposing substances, whose physical and chemical properties are still possible to distinguish, and they include carbohydrates, proteins, amino acids, fats, dyes, organic acids and other substances with low molecular weights. Their survival time in the soil is short because their vehicles are attacked by the soil microorganisms.

2. Humic substances (humified substances), which constitute the largest proportion of organic matter, as it is about $(65-80 \%)$ and includes a mixture of heterogeneous and amorphous materials with high molecular weight, divided according to their molecular weight and their solubility properties and their degree to Fulvic acid and Humic acid Humic acid and humain.

There is another division of organic matter according to its chemical composition, according to which the organic matter is divided into (non-nitrogenous organic compounds) and includes carbohydrates (mono, two, three and multiple sugars such as cellulose, hemicellulose, pectin and glucose), lycene, organic acids, their salts, fats and oils, and (organic nitrogen compounds) and include proteins and proteins Polypeptides, amino acids, purines and nucleic acids (Havlin $\boldsymbol{e t}$ al., 2005). Several studies have indicated different soils in their organic matter content, as soils contain $1 \%$ and the least organic matter is considered poor from the soil with its content of organic matter, while soils containing $2 \%$ or more organic matter are considered to be rich in organic materials and this difference may be due to many factors, including the type of plants present and the nature of microorganisms in the soil and service operations agricultural conditions, prevailing environmental conditions in the region, and organic additives (Bot and Benites, 2005).

The importance of organic matter: Various sources indicated the role and importance of organic matter and the features it adds to soil, Morlat and Chaussod (2008), Hossain et al. (2017) have shown the effective role of organic fertilizers when adding soil to improving chemical, physical and biological soil properties by:

1- It is a good source of NPK and micro nutrients, and when decomposed biologically, quantities of these elements are released, so the plant can benefit from it, as it works to convert many nutrients to the ready-to-absorb image as a result of adjusting the degree of soil interaction, as it increases the acidity of the base soil and reduces From the acidity of acidic soils.

2- It works to restrict and chelate nutrients (organic materials that have the ability to surround a specific element at a suitable $\mathrm{pH}$ degree and may be natural or industrial organic) and then protect it from washing, especially when added to light soils, because of its large surface area in relation to its weight as well as containing groups effective as carboxyl, hydroxyl and phenol.

3 - It increases the effectiveness and numbers of microorganisms and their types, as it is a source of carbon and the energy needed for beneficial organisms such as earthworms, bacteria and fungi.

4- Regulating soil against rapid changes due to acidity, alkalinity, salinity, chemical pesticides and toxic heavy metals.

5- It works to reduce the crust formation at the surface of the soil by increasing the cohesion of the soil grains, as well as reducing its separation that occurs as a result of rainfall.

6- It improves soil composition and maintains the stability of its clusters. The organic matter also reduces the apparent density of the soil, increasing its porosity and increasing its aeration.

7- The organic matter increases the soil's ability to hold water, as the organic materials are only colloids that absorb water. Therefore, adding 
the organic matter directly in the form of fertilizers or indirectly increases the resistance of such lands to drought.

8- The decomposition of the organic matter produces many organic acids as well as the carbon dioxide that dissolves in the ground solution, forming carbonic acid. These individual organic acids from the decomposition of the organic matter dissolve many of the nutrients present in the soil and make them more suitable for absorption by trees, especially elements. Phosphorus, iron, zinc and manganese.

9- When decomposing organic fertilizers in the soil as a result of the activity of microorganisms, it is accompanied by the release of thermal energy. This energy can be used as a means to warm the roots of plants in the winter season, as well as its role in increasing the ability of the roots to absorb water and nutrients because it increases the effectiveness of the roots and increases their breathing. Hence the production of energy necessary to absorb some of the nutrients and as a result the plant growth and production improves.

The term organic matter in the soil is expressed by all plant and animal substances originating in the soil or added to it, regardless of the stages of decomposition that have reached it. The term includes the roots of the different plants and the plant parts that are left in the soil or embedded in it by agricultural processes and the bodies of different animals such as worms and insects as well as living organisms. The micro found in the soil and thus include the organic matter in the soil both the relatively large decomposing part and the colloidal part that has reached a large stage of decomposition and has become a contribution to the physical and chemical properties of the soil and then to crop production (Hossain et al. 2017). On this basis, there are many organic fertilizers that are added to the soil, the most important of which are animal waste, sewage waste, factory waste, poultry and fish waste, as well as industrial organic fertilizers (Compost), which are fertilizers made from crop residues such as straw, corn waste, gardens, weeds and animal waste and others, organic fertilizers are prepared from different sources as they may be plant, animal or industrial wastes, which are either solid or liquid, or fresh or decomposed, and added to various plants in various ways and in quantities estimated according to the type of crop, soil, prevailing environmental conditions and the ratio of solid / liquid materials in compost and others. (Adiaha, 2017).

\section{The importance of liquid organic fertilizers}

The importance of using liquid organic fertilizers has emerged as it is one of the most important clean alternatives to the nutrients needed by fruit plants because it contains some organic acids such as humic and fulvic acids and amino acids and other materials that are characterized by cheap price and ease of use and low pollution to the environment and agricultural products and their contribution to improving the physical, chemical and biological characteristics Soil, which is reflected positively in the growth and production of different plants (Al-Aareji et al., 2014. Also, these substances are absorbed by the roots of the plant and liberate their ions easily and move quickly so that the plant can benefit from it by participating in the physiological processes, providing the plant with the energy necessary to absorb it, especially in the critical stages of its growth (Hassan et al., 2010). In addition to that this fertilizer contains organic nitrogen, which turns into mineral nitrogen by the activity of the microorganisms present in the soil, which is absorbed by the seedlings and works to increase the construction of chlorophyll and organic carbon, which enters the composition of all organic compounds and constitutes $50 \%$ of the dry weight of most plants (Toushan et al., 2000). It also contains organic matter which is of great importance in improving the physical and biological properties of the soil by dismantling the heavy soil granules and improving their ventilation as well as increasing the ability of the soil to retain water as well as containing a large number of amino acids that increase the activity of various physiological activities in the plant in a way directly or indirectly through its role in the formation of nucleotides, vitamins, growth regulators and enzymes (Abdel Hafiz, 2006), amino acids are also involved in building cell membranes and encouraging the formation of roots and chlorophyll, which is reflected in improving the efficiency of photosynthesis (Singh, 1999).

Several studies indicated that adding liquid organic fertilizers to fruit plants, including citrus fruits, leads to an increase in the soil 
content of ready-to-eat nutrients for the plant, which reflects positively on the characteristics of vegetative and root growth and the content of plant leaves of mineral elements necessary for their growth.

The effect of adding liquid organic fertilizers on the characteristics of vegetative and root growth and the leaf content of chlorophyll and carbohydrates for fruit seedlings

Alalaf (2012) found that when adding humic acid at three levels $(0,1$, and $2 \mathrm{ml}$. Liters $^{-1}$ ) for one-year seedlings of Eriobotrya japonica Lindl, seed age of one year, that the fertilizer parameters for humic acid used in the study scored significantly compared to the nonfertilized seedlings (control) Most of the studied characteristics (the highest increase in the length and diameter of seedlings, the percentage of chlorophyll in the leaves, the number of leaves, the leaf area, the soft and dry weight of the leaves).

Al-Tahafi et al. (2013) concluded in their experiment to study the effect of terrestrial addition and spray with organic fertilizer Siapton containing a number of amino acids in three concentrations (zero, 2 and $4 \mathrm{ml}$. Liters ${ }^{-1}$ ) in the vegetative growth of sour orange seedlings. There were significant differences when adding or adding the fertilizer ground Spray on the vegetative total of seedlings or the overlap between them in all characteristics of vegetative growth (the highest rate of plant height, number of branches, number of leaves and leaf area of the plant) compared to untreated seedlings.

Al-Aareji et al. (2014) in a study showing the effect of fertilization in four types of soluble organic fertilizers (humic acid, org, neutregrin and vitamin plus), in addition to the comparison treatment in some characteristics of vegetative growth of the seedlings of Eunobotrya japonica Lindl, arrived at fertilizing with $2 \mathrm{ml}$. liter ${ }^{1-}$ of nitrogen fertilizer gave the highest averages of the number of leaves on seedlings, the area of one leaf, the leafy area of the seedlings, the increase in the length of the main stem and the dry weight of the leaves.

Alalaf and Shayal Al-Alam (2014) found that the treatment of seedlings of two varieties of figs were black Dyala and White Adriatic at a concentration of $5 \mathrm{ml}$. liter ${ }^{1-}$ of neutregrin fertilizer significantly outperformed the comparison treatment in most studied vegetative growth characteristics (increase in main stem diameter, number of leaves, leafy leaf area per leaf, seedlings, soft and dry weight of leaves).

Al-Hayani et al. (2014) concluded that adding humic acid at a concentration of $1 \%$ for each anvil with irrigation water and with three additions and for 30 days between addition and another for three seedlings of three-year-old citrus fruits resulted in a significant increase in most vegetative growth characteristics under study (main stem length and diameter Leg, leaf area, and dry weight of the root and vegetative system) compared to the comparison treatment.

Ammaria et al. (2015) found that the addition of humic acid to Limon seedlings of one-year-old, inlaid with sour orange origin and growing in calcareous soils, increased the chlorophyll content in the leaves.

In a Hassan (2017) to show the effect of spraying a green plant fertilizer solution on the growth of Olea europaea seedlings, the results showed that spraying with green plant fertilizer at a concentration of $10 \mathrm{ml}$. liter ${ }^{1-} \mathrm{He}$ scored significantly in the characteristics of vegetative and root growth (height of seedlings, number of leaves, leaf area, and dry weight of the root and vegetable total) of olive seedlings compared to other treatments.

Al-Badrani (2017) found that spraying liquid fertilizer Vegeamino at a concentration of $3 \mathrm{mg}$. liter ${ }^{1-}$ Olea europaea seedlings positively affected the vegetative and root characteristics of the treated seedlings compared to the untreated seedlings.

Qaba (2019) concluded that adding amino Alexin liquid fertilizer at a concentration of 5 ml. Liters ${ }^{-1}$ liter (4\% free amino acids, $30 \%$ $\mathrm{P}_{2} \mathrm{O}_{5}$ and $20 \% \quad \mathrm{~K}_{2} \mathrm{O}$ ) gave the highest averages of the amount of chlorophyll in the leaves, the concentration of carbohydrates in the leaves, the area of one leaf and the number of branches Seedlings height and dry weight of the vegetable total of olive seedlings.

Nagham et al. (2020) concluded that the addition of liquid neutregrin fertilizer to sour orange seedlings of two years old resulted in an increase in the length and diameter of seedlings and the number of leaves compared to the control seedlings. 
The effect of adding liquid organic fertilizers on the content of leaves of fruit seedlings of nutrients

Ismail (2011) in his experiment to study the response of young olea europaea trees to paper feeding with a selective solution (Selector- $\mathrm{x}$ ) containing (amino acids by $7 \%$, organic acids and your weight in vitamins by $5 \%$ ) led to an increase. The percentage of phosphorus, potassium and leaf content of boron, especially when using this solution, at a concentration of 2 $\mathrm{ml} . \mathrm{L}^{-1}$, while the percentage of dry matter and nitrogen was not affected.

Hagag et al. (2012) reported that the treatment of olive seedlings with organic fertilizer had a significant effect in increasing the percentage of nutrients $\mathrm{N}, \mathrm{P}$ and $\mathrm{K}$ in the leaves.

It was found for Al-Badrani (2017) when spraying liquid fertilizer Vegeamino at a concentration of $3 \mathrm{mg}$. liter ${ }^{1-}$ olive seedlings increased the nutrient content of the treated seedlings compared to the untreated seedlings.

Mohamed (2018) in his study to add liquid organic fertilizer with four concentrations (zero, 2, 4 and $6 \mathrm{ml} . \mathrm{L}^{-1}$ ), reached two seedlings of olive cultivars that the concentration was 4 ml. $\mathrm{L}^{-1}$ caused a significant increase in the nitrogen concentration in the leaves and for both cultivars compared to the comparison treatment.

The results of the Al-Akaychi (2018) showed that the treatment of local orange seedlings at a concentration of $5 \mathrm{ml} . \mathrm{L}^{-1}$ of humic acid gave the highest significant increase in the ratio of nitrogen in the leaves and roots, the ratio of phosphorus in the leaves and roots, the ratio of potassium in the leaves and roots, ready nitrogen in the soil, ready phosphorus in soil $\mathrm{pH}$.

Qaba (2019) found that the addition of liquid amino fertilizer amino Alexin at a concentration of $5 \mathrm{ml} . \mathrm{L}^{-1}$ containing (4\% free amino acids and $30 \% \mathrm{P}_{2} \mathrm{O}_{5}$ and $20 \% \mathrm{~K}_{2} \mathrm{O}$ ) had no significant effect compared to the treatment compared to the concentration of nutrients in the leaves (nitrogen, phosphorous and potassium) for seedlings of two cultivars of olives.

Alalaf and Hadeed (2020) concluded that adding liquid fertilizer nitrogenine containing organic matter reduced the $\mathrm{pH}$ of the soil in which the local grafted orange seedlings were grown, which increased the readiness of major and minor nutrients, and this reflected positively in the growth of seedlings.

\section{CONCLUSIONS}

Through the results of the studies that were presented, it was revealed the positive effect of liquid organic fertilizers in improving the characteristics of the vegetative and root growth of the various fruit seedlings, as well as its role in increasing the leaf and soil content of mineral elements in a ready manner, which was clearly reflected in obtaining strong fast-growing seedlings and thus speed It reaches the fruiting stage.

\section{REFERENCES}

Abdel Hafiz, A. A. (2006). The use of amino acids and vitamins to improve the performance, growth and quality of horticultural crops under Egyptian conditions. Agricultural flyer. Scientific office of the United Company for Agricultural Development. Cairo.

Adiaha, M. S. (2017). The Role of Organic Matter in Tropical Soil Productivity. World Scientific News 86(1): 1-66.

Al-Aareji, J. M; Alalaf, A. H. and Shayal Alalam, A. T. (2014). The response of loquat (Eriopotrya japonica Lindi) seedlings to different of sources of liquid organic fertilizers application. J. Kirkuk Univ. Agric. Sci., 5(2): 11-19.

Al-Akaychi, S. Ali (2018). The response of local Citrus sinensis L. seedlings to organic and bio-fertilization. Master Thesis. faculty of Agriculture. University of Kufa. Iraq.

Alalaf, A. H. and Hadeed, N.N. (2020 B). Effect of chemical, organic and biological fertilizers on the availability of some nutrients in grafted orange seedlings. Middle East J. Agric. Res., 9 (1).

Alalaf, A. H. and Shayal Alala, A. T. (2014). Effect of organic fertilizer Nutrgreen and salicylic acid foliar spray on growth of Fig transplants cvs Aswad Diala and White Adritic. Mesopotamia J. Agric., 42(1): 21 - 30.

Alalaf, A. Hani (2012). Effect of urea and humic acid application on vegetative growth of 
loquat seedlings. Mesopotamia J. Agric., 40 (4): 22-31.

Alalaf, A. Hani (2019). Effect of budding date and Chemical, Organic and bio fertilization on budding success of local orange and subsequent growth of the seedlings. Ph.D. Thesis. Hort. \& Landscape design Dept. College of Agric. \& Forestry, Mosul Univ., Iraq.

Al-Badrani, J. M. (2017). Response of Olea europaea L. seedlings Manzanilo cultivar to add Vegeamino manure and spray with nourishing solution Fertinova and gibberellic acid $\mathrm{GA}_{3}$. Master Thesis, Technical College Al-Musayyib. Middle Euphrates University. Iraq.

AlcaAntara, B.; Mary, R.; Almudena, B. and Francisco, L. (2016). Liquid Organic Fertilizers for Sustainable Agriculture: Nutrient Uptake of Organic versus Mineral Fertilizers in Citrus Trees. PLoS ONE 11(10): 0161619. doi:10.1371/journal.

Al-Hayani, A.; Al-Samarrai, A. A. and AlShammari, M. F. (2014). The effect of pollination with a fungus. Trichoderma spp and organic fertilizer with Humic Acid and Algex marine extract in the growth of some citrus origins. Diyala J. Agric. Sci., 2 (6): 96-106.

Al-Mawsali, M. A. (2019). Complete fertilizer and fertilization - soil, plant and water analysis. Scientific Books House. Beirut.

Al-Tahafi, S. A.; Al-Hamami, S. A. and Yaqoub, N. A. (2013). The effect of grounding and spraying with Siapton $10 \mathrm{~L}$ on the vegetative growth of Citrus aurantium L. seedlings. Al-Anbar J. Agric. Sci., 11(2): 74 82.

Alwan, J. M. and Al-Hamdani, I. A. (2012). Organic farming and the environment. Ibn $\mathrm{Al}$ Atheer House for Printing and Publishing. University of $\mathrm{Al}$ Mosul. Iraq.

Ammaria,T.G; Al-Zubi, Y.; AbuBakerb, S. and Qrunflehb, I. (2015). Humic acid-like substances extracted from compost improve $\mathrm{Fe}$ nutrition of lemon grown on calcareous soil: an environmentally safe approach. Communications in Soil Science and Plant Analysis. (1- 11).

Barakat, M. R.; Yehia, T.A. and Sayed, B.M. (2012). Response of Newhall Naval Orange to bio-organic Fertilization under Newly
Reclaimed Area Conditions I: Vegetative Growth and Nutritional Status. J. Hortic. Sci. \& Ornamental Plants.4(1):18-25.

Bot, A. and Benites, J. (2005). The importance of soil organic matter. Food and Agriculture Organization of the United Nations Rome.

Hagag, L. F.; Abd El-Migeed, M.M.M.; Shahin, M.F.M.; Hassan, H.S.A. and ElAshry, S. (2012 b). Effect of mineral and organic fertilization rates on vegetative growth and $\mathrm{N}, \mathrm{P}, \mathrm{K}$ leaf content of olive seedlings $\mathrm{cv}$. Koroneiki. Australian J. Basic and Appl. Sci., 6(7):570-576.

Hassan, H.S; Sarrwy, S.M and Mostafa, E.A. (2010). Effect of foliar spraying with liquid organic fertilizer, some micronutrients, and gibberellins on leaf mineral content, fruit set, yield and fruit quality of " Hollywood" plum trees. Agric. Biol. J. North America, 1 (4):638643.

Hassan, M. M. (2017). The effect of spraying with plant green and more growth fertilizer solution on the growth of Olea europaea L. seedlings. Al-Anbar J. Agric. Sci., 51: 334-342.

Havlin, J.L; Beaton, J.D.; Tisdale, S.L. and Nelson, W.L. (2005). Soil Fertility and Fertilizers $.7^{\text {th }}$ edt. Upper Saddle River, New Jersey.

Hossain, M.Z.; Fragstein, P.V. and Heb, N.J. (2017). Effect of different organic wastes on soil properties and plant growth and yield: a Review. Scientia agriculturae bohemica, 48, (4): 224-237.

Ismail, A. A. (2011). Response of Olea europaea L. Young Olive Trees Sorani cultivar to leaf feeding with amino acids, organic and boron. Anbar J. Agric. Sci., 9 (2): 184--196.

Mansour, A.E.M and Shaaban, E.A. (2007). Effect of different sources of mineral $\mathrm{N}$ applied with organic and bio-fertilizers on fruiting of washington navel orange trees. J. Appl. Sci. Res., 3(8): 764- 769.

Mohamed, W. K. (2018). Improving the growth of seedlings of two olive varieties with some fertilizer treatments and spraying with salicylic acid. Master Thesis. College of Agriculture and Forestry. University of Mosul. Iraq.

Morlat, R. and Chaussod, R. (2008). Longterm additions of organic amendments in a 
Loire Valley vineyard. I. Effects on properties of calcareous sandy soil. Amer. J. Enol. Vitic., 59 (4): $353-363$.

Nagham S. S., Alalaf, A. H. and. Shayal Alalam, A. T (2020). Response of Sour Orange seedlings to application of gibberellic acid and nutrigreen Fertilizer. Future J. Agric., 1: 1-5.

Qaba, A. H. (2019). Response of Olea europaea L seedlings. Classify by my lover and ferocious to add sulfur and compound and organic fertilizer Amino Alexin. Master Thesis. College of Agriculture and Forestry. University of Al Mosul. Iraq.

Qaba, A. H. (2019). Response of the olive seedlings. Olea europaea to add sulfur and organic fertilizer and organic Amino Alexin. Master Thesis. College of Agriculture and Forestry. University of Mosul. Iraq.

Schnitzer, M. (1991). Soil organic matter. Soil Science, 151-158.

Singh, B.K. (1999). Plant Amino Acids: Biochemistry and Biotechnology. Marcel Dekker Inc.; New York, USA, 648.

Toushan, H. F. A.; Hamwi, M.; Baghdadi, M. and Al-Din Khalasi, H. (2000). Basics of plant physiology. The theoretical part. faculty of Agriculture. Publications of the University of Aleppo. Syria. 